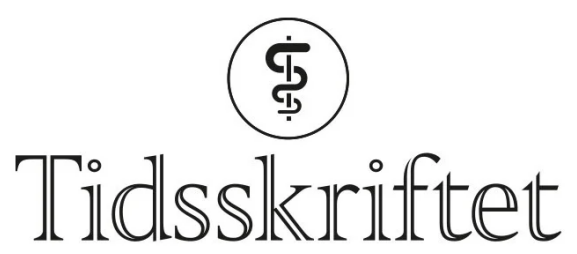

DEN NORSKE LEGEFORENING

\title{
M. Telstø svarer:
}

\author{
BREV TIL REDAKTØREN
}

\section{MERETE TELST $\varnothing$}

Merete Telstø (f. 1963) har jobbet med kulturformidling for hørselshemmede i regi av Kulturdepartementet.

Ingen oppgitte interessekonflikter.

Email:miamte@online.no

Sikring av funksjonshemmedes helse og deres mulighet til å leve et mest mulig normalt liv står sentralt i FNs konvensjon om økonomiske, sosiale og kulturelle rettigheter (ØKS) (1). Staten skal altså sikre retten til helsetilbud på et ikke-diskriminerende grunnlag, særlig at disse også sikres for sårbare og marginaliserte grupper. Retten gjelder altså den høyest oppnåelige helse, jf. konvensjonens artikkel 12. Oppnåelsen av dette avhenger dels av forholdene i samfunnet som helhet, sosialt og miljømessig, forholdene i den gruppen eller det miljøet, enten det er tegnspråkmiljø eller normaltfungerende miljø, der personen har

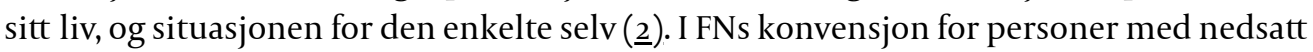
funksjonsevne av 13. desember 2006 (3), artikkel 3 om generelle prinsipper pkt. h finner vi i utgangspunktet retten til identitet for funksjonshemmede - den lyder som følger: «Respekt for de utviklingsmuligheter som barn med funksjonshemming har, samt respekt for deres rett til å bevare deres identitet».

Bevaring av identitet er også nedfelt i FNs konvensjon om barnets rettigheter av 2o.november 1989 (4).), artikkel 8 som lyder: «1. Partene forplikter seg til å respektere barnets rett til å bevare sin identitet, herunder statsborgerskap, navn og familieforhold som anerkjent av loven, uten ulovlig innblanding. 2. Dersom et barn ulovlig blir fratatt sin identitet helt eller delvis, skal partene yte egnet bistand og beskyttelse med henblikk på hurtig gjenoppretting av hans eller hennes identitet.» Plikten til å legge forholdene til rette for samtaler om egen hørsel, gjelder i utgangspunktet for alle voksne og barn. Dette innebærer at norsk helsetjeneste skal kunne legge forholdene til rette, slik hørende og hørselshemmede på menneskerettslig grunnlag får si sin mening om eget valg av språk, kommunikasjon, identitet og hørsel.

\section{LITTERATUR}

1. Konvensjon om økonomiske, sosiale og kulturelle rettigheter. www.globalis.no/Avtaler/Konvensjon-om-oekonomiske-sosiale-og-kulturelle-rettigheter (10.9.2012).

2. Eide A. Retten til helse som menneskerettighet. Nordisk Tidskrift for menneskerettigheter 2oo6; 24:274-290. 
3. FN-konvensjon om rettighetene til mennesker med nedsatt funksjonsevne. www.regjeringen.no/nb/dep/bld/tema/likestilling-og-diskriminering/funksjonsnedsettelser/fnkonvensjon-om-rettighetene-til-mennes.html?id=511768 (10.9.2012).

4. FNs barnekonvensjon. www.regjeringen.no/upload/kilde/bfd/red/200o/oo47/ddd/pdfv/178931fns_barnekonvensjon.pdf(10.9.2012).

Publisert: 2. oktober 2012. Tidsskr Nor Legeforen. DOI: 10.4045/tidsskr.12.1016

(c) Tidsskrift for Den norske legeforening 2023. Lastet ned fra tidsskriftet.no 26. april 2023. 